\title{
Giresun ilindeki sığırcılık işletmelerinin genel yapısının belirlenmesi*
}

\section{Determination of general structure of cattle enterprises in Giresun province}

\author{
Sezai ALKAN'1, Haydar ÜNLÜ ${ }^{2}$ \\ ${ }^{1}$ Ordu Üniversitesi, Ziraat Fakültesi, Zootekni Bölümü, Ordu \\ ${ }^{2}$ Giresun Tarım ve Orman İl Müdürlüğü, Giresun
}

Sorumlu yazar (Corresponding author): S. Alkan, e-posta (e-mail): sezaialkan61@gmail.com

Yazar(lar)e-posta (Author e-mail): haydarunlu28@hotmail.com

MAKALE BILLGISİ

Alınış tarihi 25 Ekim 2018

Düzeltilme tarihi 21 Kasım 2018

Kabul tarihi 21 Kasım 2018

\section{Anahtar Kelimeler:}

Giresun ili

Sığırcılık işletmesi

Sorun

\begin{abstract}
ÖZ
$\mathrm{Bu}$ çalıșma, Giresun ilindeki sığırcılık işletmelerinin genel yapısının belirlenmesi amacıyla yürütülmüştür. Çalışmada Giresun ilinin merkezinde ve ilçelerinde bulunan sığırcıllk işletmelerinde yapılan anketlerden elde edilen veriler kullanılmıştır. Anket yapılan işletmeler hayvan sayılarına göre $\leq 5$ baş, 6-15baş, 16-29 baş ve $\geq 30$ baş olmak üzere dört kategoriye ayrılmıştır. İncelenen işletmelerin \% 19.27'sinde yerli irk, \% 47.50'sinde melez, \% 20.33'ünde kültür ırkı ve \% 11.99'unda yerli+melez+kültür ırkı sı ğırlar kullanılmaktadır. Doğum bölmesi olan işletmelerin oranı \% 7.59, doğum bölmesi olmayan işletmelerin oranı ise \% 91.65 olarak belirlenmiştir. İşletmelerin \% 36.27'sinde buzağı bölmesinin bulunduğu, $\%$ 62.82'sinde ise bulunmadığı tespit edilmiștir. Kayıt tutulan işletmelerin oranı \% 15.93 , kayıt tutulmayan işletmelerin oranı ise \% 82.85 olarak belirlenmiştir. İşletmelerin $\%$ 88.01'inde sağımın elle yapıldığı ve süt analizi yaptırmayan işletmelerin oranının $\% 93.93$ olduğu tespit edilmiş̧ir. Suni tohumlama yaptıran işletmelerin oranı \%63.13 olarak saptanmıştır. Ahırların \% 71.17'sinde zeminin beton olduğu tespit edilmiştir. İşletme sahiplerinin \% 78.15'inin okuryazar/ilkokul mezunu olduğu belirlenmiş olup işletme sahiplerinin \% 53.41'inin herhangi bir tarımsal örgüte üye olmadığı tespit edilmiştir.
\end{abstract}

\section{ARTICLE INFO}

Received 25 October 2018

Received in revised form 21 November 2018

Accepted 21 November 2018

\section{Keywords:}

Giresun province

Cattle enterprise

Problem

\begin{abstract}
This study was carried out to determine the general structure of cattle breeding enterprises in Giresun province. In the study, the data obtained from the surveys conducted in the cattle enterprises in the center and districts of Giresun province were used. According to animal numbers, surveyed cattle enterprises were divided into four categories: $\geq 5$ animals, 6-15 animals, 16-29 animals and $\leq 30$ animals. In the investigated enterprises, domestic breed is used in 19.27\%, crossbred in $47.50 \%$, culture breed in $20.33 \%$ and domestic+crossbred+culture breeds in $11.99 \%$. The ratio of enterprises with birth chamber was determined as $7.59 \%$ and the ratio of those without birth chamber was found as $91.65 \%$. It was determined that $36.27 \%$ of the enterprises have a calf chamber and $62.82 \%$ of the enterprises have no calf chamber. The ratio of recorded enterprises was determined as $15.93 \%$ and the ratio of non recorded enterprises was found as $82.85 \%$. It was determined that in $88.01 \%$ of the enterprises milking was performed by hand and in $93.93 \%$ of the enterprises milk analysis was made. The proportion of enterprises having artificial insemination was $63.13 \%$. It was found that $71.17 \%$ of the enterprises have concrete floor. It was determined that $78.15 \%$ of business owners were literate / primary school graduates. It has been determined that $53.41 \%$ of enterprises owners are not members of any agricultural organization.
\end{abstract}

"BY: 1707 nolu Yüksek Lisans tezinden derlenmiş̧ir.

\section{Giriș}

İnsanların sağlıklı ve dengeli bir yaşam sürdürebilmeleri için bitkisel gıdaların yanı sıra hayvansal gıdaları da yeterli ve dengeli bir şekilde alınması gerekmektedir. Ülkelerin gelişmişlik düzeyleri arttıkça, hayvansal gıdalara da olan talep artmaktadır. Türkiye'de kiși başına düșen hayvansal protein tüketimi ortalama $36 \mathrm{~g} \mathrm{gün}^{-1}$ iken, Avrupa Birliği ülkelerinde
60 g gün $^{-1}$ ve A.B.D'de ise 70 g gün $^{-1}$ dür (Tapk1 ve ark. 2018). Hayvansal gıdaların başında süt ve ürünleri ile et ve ürünleri gelmektedir. Kişi başına hayvansal kökenli gıdaların tüketiminde gelişmiş ülkelerle geri kalmış ve gelişmekte olan ülkeler arasında önemli farklılığın olduğu bilinmektedir. Gelecekte gelişmiş ülkelerde hayvansal kaynaklı gidalara olan 
talepte önemli bir artış beklenmezken, 2020'li yıllarda nüfusu hızla artan gelişmekte olan ülkelerde et ve süte olan talebin 2 kat artabileceği bildirilmektedir (Hocquette ve Gigli 2005). Hayvancılık gelişmiş ülkelerde bir endüstri haline gelmiş ve ekonominin önemli bir parçası olmuştur. $\mathrm{Bu}$ durum hayvancılığın ulusal düzeyde geliştirilmesi gereken önemli bir sektör olduğunu ortaya koymaktadır (Anonim 2015).

Sığırlar süt ve kırmızı et üretiminde önemli bir yere sahiptir. Türkiye'de üretilen sütün \% 90.6's1 ve üretilen kırmızı etin ise $\%$ 85'i sığırlardan elde edilmektedir. Türkiye'nin toplam sığır varlığı yaklaşık 15.9 milyon baş ve bunun 5.9 milyon başı sağmal durumda olup 18.7 milyon ton sığır sütü üretilmektedir (Anonim 2017). Türkiye'de sığır yetiştiriciliği hayvancılık faaliyetleri içerisinde önemli bir yer tutmasına rağmen hayvan başına elde edilen süt verimi yeterli düzeyde değildir. İnek başına süt üretimi A.B.D'de ortalama $9.840 \mathrm{~kg}$, Avrupa Birliği ülkelerinde ortalama $6.466 \mathrm{~kg}$, Türkiye'de ise ortalama olarak $3.000 \mathrm{~kg}$ civarındadır (Hozman ve Akçay 2016).

Sığırların verim özellikleri hayvana ait genetik faktörlerin yanı sıra bakım, besleme, barınak koşulları ve sürü yönetimiyle ilgili olan çevresel faktörlerin etkisi altındadır. Bundan dolayı, verim özelliklerinin iyileştirilebilmesi için hayvanların genetik kapasitelerinin ve verim üzerine etkili çevre şartlarının optimum hale getirilmesi gerekmektedir. $\mathrm{Bu}$ nedenle, istenilen verim performansın elde edilebilmesi için genetik potansiyeli yüksek hayvanların kullanılmasının ve en uygun bakım-besleme koşullarının uygulanmasının yanı sıra hayvanlara uygun barınak şartlarının sağlanması da son derece önemlidir. Üretim yönü, hayvanların özellikleri ve bölgenin iklim koşulları göz önünde bulundurulmadan yapılan barınaklar hayvanların yaşam standardını ve verimlerini sonuç olarak da işletme kârlılığını olumsuz olarak etkilemektedir (Bardakçığlu ve ark. 2004; Akman 2006). Sı ğırlardan sahip oldukları genotipin gerektirdiği optimum verimin alınabilmesi için öncelikli olarak barınaklar uygun şekilde projelendirilmeli, bakım-besleme ve sürü yönetimi gibi çevre faktörleri de iyi düzenlenmelidir. Hayvanlardan hedeflenen verimin alınmasının temel şartı; genetik kapasitelerinin arttırılması yanında hayvanların içerisinde bulundukları çevre şartlarının da iyileştirilmesidir.

$\mathrm{Bu}$ araştırmada, Giresun İlinde faaliyette bulunan sığırcılık işletmelerinin genel yapılarının ve sorunlarının belirlenmesi amaçlanmıştır.

\section{Materyal ve Yöntem}

Giresun ilinde kayıtlı 20916 sığırcılık işletmesi bulunmaktadır (Anonim 2016). Bu araştırmanın materyalini, Giresun ilindeki 20916 sığırcılık işlemesinden tabakalı örnekleme yöntemine göre seçilen toplam 659 adet işletme oluşturmuştur. İşletmeler büyüklüklerine göre $\leq 5$ baş, $6-15$ baş, $16-29$ baş ve $\geq 30$ baş olmak üzere 4 farklı gruba ayrılmıştır. Örneğe girecek işletme sayıları \% 1 hata payı $(\alpha) \% 99$ güven aralığı dikkate alınarak ayrı ayrı hesaplanmıştır (Yamane 1967).

$$
n=\frac{N \sum N_{h} S_{h}{ }^{2}}{N^{2} * D^{2}+\sum N_{h}{S_{h}}^{2}}, \quad D^{2}=\frac{d^{2}}{Z^{2}}
$$

Formülde;

$\mathrm{n}=$ örnek hacmi

$\mathrm{N}=$ Populasyondaki toplam işletme sayısı

$\mathrm{N}_{\mathrm{h}}=$ h. tabakadaki işletme sayısı

$\mathrm{S}_{\mathrm{h}}=\mathrm{h}$. tabakadaki standart sapma $\mathrm{d}=$ Populasyon ortalamasından izin verilen hata miktarı $\mathrm{Z}=$ İzin verilen hata miktarına göre Z-tablo değeri.

Belirlenen örnek genişliğinin tabakalara dağıtımında orantılı dağıtım yöntemi kullanılmış ve aşağıdaki formül ile tabakaların genişlikleri hesaplanmıştır. Anketlerin değerlendirilmesinde SPSS İstatistik Paket Programı kullanılmıştır (Anonim 2008).

$$
n_{h}=\left(\frac{N_{h}}{N}\right) n
$$

Formülde;

$\mathrm{n}_{\mathrm{h}}=\mathrm{h}$. tabakadaki anket sayıs 1

$\mathrm{N}_{\mathrm{h}}=\mathrm{h}$. tabakadaki işletme sayısı

$\mathrm{N}=$ Toplam işletme sayısı.

Araştırmada anket uygulanan sığırcılık işletmelerinin tabakalara göre \% 1 hata payı ile dağılımı Çizelge 1'de verilmiştir.

Çizelge 1. İşletmelerin tabakalara göre dağılımı.

Table 1. Distribution of enterprises by classification.

\begin{tabular}{cccc}
\hline $\begin{array}{c}\text { İşletme } \\
\text { Büyüklüğü }\end{array}$ & İşletme Sayısı (Nh) & Nh / N & $\begin{array}{c}\text { Anket Sayısı } \\
(\mathrm{n})\end{array}$ \\
\hline ×5 Baş & 14.057 & 67.2 & 359 \\
6-15 Baş & 4.979 & 23.8 & 188 \\
16-29 Baş & 1.402 & 6.7 & 66 \\
$\geq 30$ Baş & 478 & 2.3 & 46 \\
& $\mathrm{~N}=20.916$ & 100 & 659 \\
\hline
\end{tabular}

\section{Bulgular ve Tartışma}

Çizelge 2'de görüldüğü gibi işletme sahiplerinin sadece $\%$ 2.28'ini okuryazar olmayanlar oluşturmaktadır. Ayrıca, işletme sahiplerinin \% 15.63 'ü ortaokul mezunu, \% 3.19'u ise lise mezunu olup üniversite mezunu olanların oranı sadece $\% 0.46$ olarak belirlenmiştir. Yapılan bazı çalışmalarda, Çağ 1 (1996) işletme sahiplerinin \% 77.5'inin ilkokul, Şahin ve ark. (2001) işletme sahiplerinin \% 57.6'sının ilkokul, Soyak ve ark. (2007) yetiştiricilerin \% 59'unun ilkokul, Demir (2011) işletme sahiplerinin \% 62.5'inin ilkokul, Demir ve Ayvazoğlu (2012) işletme sahiplerinin \% 45.6'sının ilkokul, Şeker ve ark. (2012) yetiştiricilerin \% 48.8'inin ilkokul terk ve ilkokul mezunu olduğunu belirlemişlerdir. Yine Tapkı ve ark. (2018) tarafından yapılan bir çalışmada, işletme sahiplerinin sadece \% 0.9 'unun okur-yazar olmadığı, \% 5.3'ünün üniversite, \% 29.5'inin ortaokul ve lise ve \% 64.3'ünün ilkokul mezunu olduğu tespit edilmiştir. Bu çalışmada işletme sahiplerinin eğitim düzeyleri genel olarak literatürde belirtilen değerlerle benzerlik göstermektedir.

Çizelge 2. İşletme sahiplerinin eğitim durumları.

Table 2. Educational status of enterprise owners.

\begin{tabular}{lrr}
\hline \multicolumn{1}{c}{ Eğitim Durumu } & $\mathrm{n}$ & \multicolumn{1}{c}{$\%$} \\
\hline Okuryazar değil & 15 & 2.28 \\
Okuryazar / İlkokul & 515 & 78.15 \\
Ortaokul & 103 & 15.63 \\
Lise & 21 & 3.19 \\
Üniversite & 3 & 0.46 \\
Cevap Vermeyen & 2 & 0.30 \\
\hline
\end{tabular}


İşletme sahiplerinin hayvancilıkla ilgili kursa/eğitime katılma durumları incelendiğinde; en büyük oranı hayvancılık ile ilgili eğitime/kursa katılmayanların (\% 81.49) oluşturduğu ve işletme sahiplerinin yalnızca \% 17.60'ının hayvancılıkla ilgili eğitime ya da kursa katıldığı anlaşılmaktadır (Çizelge 3). Tapkı (1996) işletme sahiplerinin hayvancılık konusunda eğitim alma oranını \% 3, Koçyiğit ve ark.(2015) \% 17 ile Bakan ve Aydın (2016) ise \% 34.3 olarak bildirmişlerdir. Yine Tapk1 ve ark. (2018) yaptıkları çalışmada, sığır yetiştiriciliği konusunda eğitim olanların oranının \% 22.32 olduğunu, bu yetiştiricilerin \% 68'inin tarım teşkilatlarından, \% 12'sinin okullardan, $\%$ 16'sının özel kuruluşlardan ve \%4'ünün de deneyimli yetiştiricilerden eğitim aldıklarını belirlemişlerdir. $\mathrm{Bu}$ çalışmadan elde edilen sonuçlara dayanarak, hayvancılıkla uğraşan yetiştiricilerin büyük bir kısmının hayvancılık alanında yaşanan yenilikleri takip etmediği ya da buna ihtiyaç duymadığ 1 ve geleneksel yöntemlerle hayvancılık yaptıkları söylenebilir.

Çizelge 3. İşletme sahiplerinin hayvancılık ile ilgili kursa/eğitime katılma durumu.

Table 3. Participating status of enterprise owners in training or course on livestock.

\begin{tabular}{lcc}
\hline Kurs/Eğitim Katılım Durumu & İşletme Sayısı & $\%$ \\
\hline Katılan & 116 & 17.60 \\
Katılmayan & 537 & 81.49 \\
Cevap vermeyen & 6 & 0.91 \\
\hline
\end{tabular}

Çizelge 4'de görüldüğü gibi, yetiştiricilerin \% 53.41'inin herhangi bir tarımsal örgüte üye olmadığı ve \% 46.59'unun ise üye olduğu anlaşılmaktadır. Hayvancılık desteklemelerinin yetiştirici birlikleri aracılığıyla yapılmasına rağmen, ankete katılan yetiştiricilerin neredeyse yarıya yakınının yetiştirici birliklerine üye olmaması sorgulanması gereken bir durum olarak ortaya çıkmıştır. Bunun nedeni araştırılmalı ve yetiştiricilerin hala neden yetiştirici birliklerine üye olmadıklarının sebepleri açık bir șekilde ortaya konulmalıdır. Demir ve Aral (2009) tarafindan yapılan araştırmada yetiştiricilerin \% 35'inin tarımsal amaçlı kooperatif ya da birlik üyesi olduğu, buna karşın \% 65'inin ise üyeliğinin bulunmadığ belirlenmiştir.

Çizelge 4. İşletme sahiplerinin tarımsal örgütlere üyelik durumu.

Table 4. Membership status of enterprise owners to agricultural organizations.

\begin{tabular}{lcc}
\hline Kooperatif/Birlik Üyeliği & İşletme Sayısı & $\%$ \\
\hline Üye & 297 & 46.59 \\
Üye olmayan & 352 & 53.41 \\
\hline
\end{tabular}

İşletmelerin \% 47.50'sinde melez sığırlar, \% 20.33'ünde kültür sığırları, \% 19.27'sinde yerli ırk sığırlar ve \% 11.99'unda ise melez + yerli ve kültür ırkı sığırlar yetiştirilmektedir (Çizelge 5). Çizelgeden de anlaşıldığı gibi işletmelerin yaklaşık olarak yarısında melez sığırlar kullanılmaktadır. Tapk1 (1996) Hatay ilinde yaptığı bir çalışmada işletmelerdeki kültür ırkı sığır oranını $\% 10$, yerli sığır ırkı oranını $\% 44$ ve melez sığırların oranını ise $\% 46$ olarak belirlemiştir. Tugay ve Bakır (2005) Giresun ilinde yürüttükleri araştırmada, hayvancilık işletmelerinin \% 23.6'sında yerli sığır irkları, \% 71.1'inde melez ve \% 5.3'ünde kültür 1rk1 bulunduğunu, Aygül ve Özkütük (2012) ise süt üretim amaçlı işletmelerde hayvan varlığının \% 94' ünün, besi sığırcılığı işletmelerinde ise \% 68'inin kültür ırklarından oluştuğunu belirlemiştir. Tapkı ve ark. (2018) tarafindan yapılan çalışmada ise işletmelerin
$\%$ 2.62sında yerli 1rk, \% 16.8'inde melez genotiplerin ve \% 80.6'sında ise kültür ırkı sığırların yetiştirildiği belirtilmiştir. Belirtilen araştırma sonuçları arasındaki farklılıkların, araștırmaların farklı zamanlarda, farklı ișletmelerde ve bölgelerde yapılmış olmasından kaynaklanmış olabileceği düşünülmektedir.

Çizelge 5. İşletmelerdeki sığır genotiplerinin dağılımı.

Table 5. Distribution of cattle genotypes in enterprises.

\begin{tabular}{lcc}
\hline Hayvan Irkları & İşletme Sayısı & $\%$ \\
\hline Yerli ırklar & 127 & 19.27 \\
Melez & 313 & 47.50 \\
Kültür ırkı & 134 & 20.33 \\
Yerli + Melez + Kültür & 79 & 11.99 \\
Cevap vermeyen & 6 & 0.91 \\
\hline
\end{tabular}

Araştırmada sığır yetiştiricilerinin \% 62.82'si en büyük problemlerinin yem fiyatlarının yüksek olduğunu belirtmişlerdir (Çizelge 6). Hayvancılık faaliyetindeki en önemli gider kaynăg 1 yem maliyetleri olup işletme maliyetinin yaklaşık olarak \% 6570'ini oluşturmaktadır. Tugay ve Bakır (2005) yaptıkları çalışmada işletmelerin sorunlarını pazar, kredi, yem fiyatının yüksekliği, süt fiyatının düşüklüğü olarak belirlemiştir. Bu çalışmada ise en önemli sorunlar yem fiyatları yüksekliği ve ürünlerin fiyatına pazarlanmaması olarak belirlenmiştir. Demir ve Aral (2009), sığırcılık işletmelerinin karşılaş̧tıkları sorunların belirlenmesi üzerine yaptıkları araștırmada; örgütlenme eksikliğinin en önemli sorun olduğunu, buna bağlı olarak üretilen sütün düşük fiyatla satıldığını ve üretimde kullanılan girdilerin fiyatlarının ise yüksek olduğunu tespit etmişlerdir. Giresun ilinde hem yem bitkilerinin yetiştirilmesi için yeterli alanın olmaması ve hem de iklim koşullarının yem bitkilerinin kurutulması için uygun olmamasından dolayı gerek duyulan kaba yem daha uzak pazarlardan temin edilmektedir. $\mathrm{Bu}$ duruma yem maliyetlerinin artması neden olmaktadır.

Çizelge 6. Sığır yetiştiriciliğin en önemli sorunları.

Table 6. The most important problems of cattle breeding.

\begin{tabular}{lcr}
\hline Sorunlar & $\begin{array}{c}\text { İșletme } \\
\text { Sayıs1 }\end{array}$ & \multicolumn{1}{c}{$\%$} \\
\hline Ürünlerin fiyatına pazarlanamaması & 55 & 8.35 \\
Yem fiyatlarının yüksek olması & 414 & 62.82 \\
Sağlık-koruma hizmetlerinin yüksek olması & 13 & 1.97 \\
Ürünlerin fiyatında pazarlanmaması + Yem & 97 & 14.72 \\
fiyatları yüksek & 34 & 5.16 \\
Yem fiyatları yüksek + Sağlık-koruma & & \\
hizmetleri & & 5.61 \\
Ürünlerin fiyatına pazarlanmaması + Yem & 37 & 1.37 \\
fiyatları yüksek + Sağlık-koruma hizmetleri & 9 & \\
Cevap vermeyen &
\end{tabular}

Çizelge 7'de görüldüğü gibi işletmelerin \% 62.22'si kaba yem ihtiyaçlarını satın alarak, \% 13.96'sı kendi arazisinde üreterek ve \%23.52'si ise hem satın alarak hem de kendi arazisinde üreterek karşılamaktadır. Görüldüğü üzere, işletmelerin önemli bir kısmı kaba yemi satın almaktadır. İşletmelerin bulunduğu bölgede yeterli ekilebilir arazinin bulunmadığından, işletmelerin önemli bir kısmı ihtiyaç duyduğu kaba yemi satın almak zorunda kalmaktadır. Bu duruma bağlı olarak ta işletmelerin üretim maliyetleri artmaktadır

İșletmelerin \% 82.40'1 kesif yemi satın almakta, \% 14.42'si hem satın almakta hem de kendisi hazırlamaktadır (Çizelge 8). Kesif yemini kendi hazırlayan işletmelerin oranı $\% 2.43$ olup oldukça düşüktür. İncelenen işletmelerin önemli bir kısmının 
kaba ve kesif yem temininde dışarıdan satın almaya bağımlı olması işletmelerin en önemli sorunu olarak ortaya çıkmakta ve yem maliyetleri olabildiğince yükselmektedir. $\mathrm{Bu}$ durum bölgedeki işletmeler için çok önemli bir sorun olup çözümü için gerekli önlemlerin alınması ve işletmelerin yem temin maliyetlerinin azaltılması gerekmektedir. Demirtaş (2006) yaptığı bir çalışmada, işletmelerin \% 50'sinde hazır yem kullanıldığını, diğer \% 50'sinde ise hazır yemin yanında kaba yem gereksinimini karşılamak amacıyla işletme arazisinde yetiştirilen yem bitkilerinin kullanıldığını belirtmiştir. Şahin ve Yılmaz (2008) tarafindan yapılan bir çalışmada ise yem bitkisi üreten işletmelerde işletme başına düşen ortalama işletme arazisinin 52.5 dekar olduğu ve işletme arazilerinin tamamının işletmecilerin mülkü olduğu bildirilmiştir. Yaptığımız araştırmada işletmelerin kaba ve kesif yem üretimi konusunda yetersiz oldukları ve önemli ölçüde dışa bağımlı oldukları belirlenmiştir.

Sığırcılık işletmelerinde sağım öncesi meme temizliği $\% 91.35$ oranında su ile yapılırken dezenfektan kullanan işletmelerin oranı \% 4.55 olarak belirlenmiştir (Çizelge 9). İşletmelerin \% 94.23'ünde günde iki sağım yapıldığı, elle sağım yapılan işletmelerinin oranının $\% 88$ olduğu ve seyyar sağım makinesi kullanım oranı ise \%9.86 olarak tespit edilmiştir. Sağmal hayvan başına günlük süt verimi 5 litreden az olan işletmelerin oranı $\% 16,08$, süt verimi 5-10 litre arasında olanların oranı $\% 68.13$, süt verimi $10-15$ litre arasında olanların oranı \% 12.29 ve süt verimi 15 litreden fazla olanların oranı sadece \% 2.28 olarak belirlenmiştir. Yetiştiricilerin genellikle süt analizi yaptırmadıkları (\% 93.93) tespit edilmiş olup üretilen sütün \% 27.31'i çiğ olarak satılmakta, \%21.70'i ise peynir ve tereyağı yapılarak değerlendirilmektedir.

Çizelge 9. İşletmelerde sağım, süt verimi ve sütün değerlendirilmesi.

Table 9. Milking, milk yield and evaluation of milk in enterprises.

\begin{tabular}{|c|c|c|c|}
\hline & $\mathbf{n}$ & Seçenekler & $\%$ \\
\hline \multirow{4}{*}{$\begin{array}{l}\text { Sağım Öncesi Meme Temizliği Yapma } \\
\text { Durumu }\end{array}$} & 602 & Su ile yapıllyor & 91.35 \\
\hline & 30 & Dezenfektan kullanılıyor & 4.55 \\
\hline & 13 & Yapilmiyor & 1.97 \\
\hline & 14 & Cevap Vermeyen & 2.12 \\
\hline \multirow{3}{*}{ Günlük Sağım Sayısı } & 30 & Bir sağım & 4.55 \\
\hline & 621 & İki sağım & 94.23 \\
\hline & 8 & Cevap Vermeyen & 1.21 \\
\hline \multirow{5}{*}{ Sağım Şekli } & 580 & Elle sağım & 88.01 \\
\hline & 65 & Seyyar sağım makinesi & 9.86 \\
\hline & 1 & Sabit sağım ünitesinde & 0.15 \\
\hline & 7 & Elle + Seyyar Makine & 1.06 \\
\hline & 6 & Cevap Vermeyen & 0.92 \\
\hline \multirow{5}{*}{ Sağmal Hayvan Başına Günlük Süt Verimi } & 106 & 5 litreden az & 16.08 \\
\hline & 449 & 5-10 litre arası & 68.13 \\
\hline & 81 & 10-15 litre aras 1 & 12.29 \\
\hline & 15 & 15 litreden fazla & 2.28 \\
\hline & 8 & Cevap vermeyen & 1.21 \\
\hline \multirow{6}{*}{ Sütün Değerlendirilmesi } & 180 & Çiğ süt satışı & 27.31 \\
\hline & 13 & Yoğurt Satış1 & 1.97 \\
\hline & 143 & Peynir - Tereyağı satışı & 21.70 \\
\hline & 247 & Çiğ Süt - İşlenmiş ürün satış1 & 37.48 \\
\hline & 13 & Satış yapmıyor & 1.97 \\
\hline & 63 & Cevap vermeyen & 9.56 \\
\hline \multirow{4}{*}{ Süt Analizi Yaptırma Durumu } & 619 & Yapılmıyor & 93.93 \\
\hline & 3 & 6 ayda bir yapılıyor & 0.46 \\
\hline & 24 & Yılda bir yapılıyor & 3.64 \\
\hline & 13 & Cevap Vermeyen & 1.97 \\
\hline
\end{tabular}

Bakır (2002) tarafindan yapılan çalışmada, sığırcılık işletmelerinde süt sağımının $\% 96.5$ oranında elle, \% 3.5 oranında makine ile yapıldığı bildirilmiştir. Demir (2011) yaptığı bir çalışmada, işletmelerin \% 87'sinde sağımın elle yapıldığını ve sağım öncesi meme temizliği yapan işletmelerin oranının \% 36.3 olduğunu belirtmiştir. Şeker ve ark. (2012) işletmelerin \% 89.6'sında hayvan başına ortalama süt veriminin $10 \mathrm{~kg}$ ve daha az olduğunu bildirmişlerdir. Şahin ve ark. (2001) ise işletmelerde süt veriminin kültür rrklarında $18.03 \mathrm{~kg} \mathrm{gün}^{-1}$, melezlerde $13.63 \mathrm{~kg} g u ̈ n^{-1}$ ve yerli irklarda ise $9.47 \mathrm{~kg} \mathrm{gün}^{-1}$ hesaplamışlardır. Şahin ve Yılmaz (2008) tarafindan yapılan araştırmada inek başına ortalama süt veriminin günlük $5.19 \mathrm{~kg}$

Çizelge 7. İşletmelerin kaba yem temini durumu.

Table 7. Status of roughage supply of enterprises.

\begin{tabular}{lrr}
\hline \multicolumn{1}{c}{ Kaba Yem Temin Şekli } & $\mathrm{n}$ & \multicolumn{1}{c}{$\%$} \\
\hline Kendi arazisinden & 92 & 13.96 \\
Satın alma & 410 & 62.22 \\
Kendi arazisi ve satın alarak & 155 & 23.52 \\
Cevap vermeyen & 2 & 0.30 \\
\hline
\end{tabular}

Çizelge 8. İşletmelerin kesif yem temin durumu.

Table 8. Status of concentrated feed supply of enterprises.

\begin{tabular}{lrr}
\hline \multicolumn{1}{c}{ Kesif Yem Temin Şekli } & $\mathrm{n}$ & \multicolumn{1}{c}{$\%$} \\
\hline Kendisi hazırlıyor & 16 & 2.43 \\
Satın alıyor & 543 & 82.40 \\
Kendisi hazırlıyor ve satın alıyor & 95 & 14.42 \\
Kesif yem kullanmıor & 1 & 0.15 \\
Cevap vermeyen & 4 & 0.60 \\
\hline
\end{tabular}


olduğu tespit edilmiştir. Sağım öncesi meme temizliği yapılırken çoğunlukla su kullanılması önemli bir sorun olarak ortaya çıkmıştır. Bu konuda yetiştiricilerin bilinçlendirilmesi ve dezenfektan kullanmalarına yönelik çalışmalar yapılmalıdır. İşletmelerin çoğunun küçük aile tipi işletmesi olmasına bağlı olarak sağım genel olarak elle yapılmaktadır. İşletmelerin önemli bir kısmında günlük süt verimi $5-10 \mathrm{~kg}$ arasındadır. Yetiştiricilerin daha verimli bir üretim yapabilmeleri için günlük süt veriminin arttırılmasına yönelik çalışmalar yapılmalıdır. En önemli sorunlardan biri de süt analizlerinin yapılmaması durumudur. Yetiştiriciler bu konuda bilgilendirilmeli ve süt analizlerinin yaptırılması konusunda yetiştiricilere gerekli teknik destek sağlanmalıdır.

İncelenen işletmelerdeki barınakların \% 57.66'sının müstakil, \% 41.12'sinin evin altında, \% 87.56'sının kapalı bağlı duraklı olduğu, \% 71.17'sinde zeminin beton ve \% 33.54'ünde duvar malzemesi olarak tuğla kullanıldı $\breve{g} 1, \% 67.98$ 'inde çatının ahşaptan oluştuğu ve \% 66.46'sında çatı örtüsü olarak sac kullanıldığı tespit edilmiştir (Çizelge 10). Yine, ahırların \% 93.78'inde hasta hayvan bölmesi \%91.65'inde doğum bölmesi \%97.88'inde sağımhane olmadığ 1 , \% 62.82'sinde buzağı bölmesi ve \% 78.76'sında ise gübre çukuru ya da fosseptik olmadığı belirlenmiştir. Tugay ve Bakır (2005) tarafından yapılan çalışmada, barınakların \% 35.7'sinin müstakil, \% 62.2'sinin evin altında, \% 2,1'inin ev altı-müstakil olduğu, barınak malzemesi olarak \%62,3 taş, \% 27.9 briket, \% 8.6 ahşap, \% 1.1 kerpiç kullanıldığı, barınak tabanının $\% 47.5$ beton, \% 42.4 tahta, \% 9.7 toprak ve \% 0.5 taş malzemeden yapıldığı, \% 49.3'ünde durak bulunmadığ 1 ve

Çizelge 10. İşletmelerdeki barınakların yapısal özellikleri.

Table 10. Structural characteristics of shelters in enterprises.

\begin{tabular}{|c|c|c|c|}
\hline & Seçenekler & $\mathrm{n}$ & $\%$ \\
\hline \multirow{3}{*}{ Ahırın Yeri } & Evin altı & 271 & 41.12 \\
\hline & Müstakil & 380 & 57.66 \\
\hline & Cevap vermeyen & 8 & 1.22 \\
\hline \multirow{5}{*}{ Ahır Tipi } & Kapalı Bağlı Duraklı & 577 & 87.56 \\
\hline & Yarı Açık Duraklı & 11 & 1.67 \\
\hline & Sundurma Tipi (Duraksız) & 50 & 7.59 \\
\hline & Cevap vermeyen & 21 & 3.19 \\
\hline & Toprak & 95 & 14.42 \\
\hline \multirow{4}{*}{ Ahırın Zemin } & Beton & 469 & 71.17 \\
\hline & Ahşap & 79 & 11.99 \\
\hline & Toprak + Beton + Ahşap & 11 & 1.65 \\
\hline & Cevap vermeyen & 5 & 0.76 \\
\hline \multirow{7}{*}{ Ahırın Duvar Yapı Malzemesi } & Briket & 116 & 17.60 \\
\hline & Taş & 194 & 29.44 \\
\hline & Tuğla & 221 & 33.54 \\
\hline & Ahşap & 4 & 0.61 \\
\hline & Sac kaplama & 2 & 0.30 \\
\hline & Briket + Taş + Tuğla & 16 & 2.57 \\
\hline & Cevap vermeyen & 105 & 15.93 \\
\hline \multirow{4}{*}{ Ahırın Çatı İskeleti } & Ahşap çatı & 448 & 67.98 \\
\hline & Çelik çatı & 36 & 5.46 \\
\hline & Beton & 7 & 1.06 \\
\hline & Cevap vermeyen & 168 & 25.49 \\
\hline \multirow{6}{*}{ Ahırın Çatı Örtü Malzemesi } & $\mathrm{Sac}$ & 438 & 66.46 \\
\hline & Kiremit & 30 & 4.55 \\
\hline & Eternit & 1 & 0.15 \\
\hline & Sandviç panel & 3 & 0.46 \\
\hline & Toprak & 10 & 1.52 \\
\hline & Cevap vermeyen & 177 & 26.86 \\
\hline \multirow{3}{*}{ Hasta Hayvan Bölümü } & Var & 34 & 5.16 \\
\hline & Yok & 618 & 93.78 \\
\hline & Cevap vermeyen & 7 & 1.06 \\
\hline \multirow{3}{*}{ Doğum Bölmesi } & Var & 50 & 7.59 \\
\hline & Yok & 604 & 91.65 \\
\hline & Cevap vermeyen & 5 & 0.76 \\
\hline \multirow{3}{*}{ Sağımhane } & Var & 9 & 1.37 \\
\hline & Yok & 645 & 97.88 \\
\hline & Cevap vermeyen & 5 & 0.76 \\
\hline \multirow{3}{*}{ Buzağı Bölmesi } & Var & 239 & 36.27 \\
\hline & Yok & 414 & 62.82 \\
\hline & Cevap vermeyen & 6 & 0.91 \\
\hline \multirow{3}{*}{ Gübre Çukuru/Fosseptik } & Var & 131 & 19.88 \\
\hline & Yok & 519 & 78.76 \\
\hline & Cevap vermeyen & 9 & 1.36 \\
\hline
\end{tabular}


\% 92'sinde altlık malzemesi olarak gazel, findık patos artığ1, saman ve kuru gübre kullanıldığı saptanmıştır. Karabacak ve Topak (2007) yaptıkları bir çalışmada, ahır çatılarının \% 20 çelikten, $\% 75$ ahşaptan ve $\% 5$ betondan yapıldığını saptamışlardır. Çatı örtü malzemesi olarak \% 55'inde kiremit, \% 25'inde sıkıştırılmış kil, \% 20'sinde ise sac kullanıldığını belirlemişlerdir. Yener ve ark. (2013) tarafindan yapılan çalışmada, süt sığırı barınakların \% 85.2'sinde zeminin beton, besi sığırı işletmelerinde ise \%93'ünün sıkıştırılmış toprak olduğu tespit edilmiştir. Aydın ve ark. (2016) yaptıkları araştırmada; ahırların \% 51.5'inin bağlı duraksız kapalı ahırlar olduğunu, ahırların \% 74.9'unda doğum bölmesi bulunmadığını, düve, dana ve kurudaki ineklerin bir arada barındırıldıklarını (\% 84.3) ve ahırların \% 81'inde altlık kullanılmadığını bildirmişlerdir. Ayrıca, gübre temizliğinin elle yapıldığını (\% 84.1), gübrenin açıkta depolandığını (\% 80.3) ve işletmelerin gübrenin \% 69.9'unu tarlaya atarak, \% 13.4'ünün yakacak olarak ve \% 11.8'ini ise satmak suretiyle değerlendirdiğini saptamışlardır. Özyürek ve ark. (2014) tarafından yapılan çalışmada, barınakların \% 97.7'sinin kapalı bağlı duraklı tip ve barınakların duvarlarının taş, briket, tuğla ve kerpiç olma durumunun sırasıyla \% 41.7, \% 24.7, \% 10.1 ve $\% 23.5$ olduğu belirlenmiştir. Yine, \% 64.7'sinin çatısının sac ve \% 93.3'ünün zemininin de beton olduğu tespit edilmiştir. Bölgede günümüzde barınakların evin altında bulunması ve çoğunun kapalı bağlı duraklı olması, buzağı bölmesi, doğum bölmesi, hasta hayvan bölmesi ve gübre ya da fosseptik çukuru bulunmaması düzeltilmesi gerek önemli sorunlar olarak ortaya çıkmıştır.

\section{Sonuç}

Elde edilen sonuçlar incelendiğinde, işletmelerde daha karlı bir hayvancılık yapılabilmesi için işletmelerin sahip oldukları hayvan sayısının arttırılması ve işletme sahiplerinin hayvancılık konusundaki teknik bilgi ve becerilerinin arttırılması gerekmektedir. Bunun için de konuyla ilgili eğitim kursları düzenlenmeli ve bu kurslarda alanında uzman kişiler görev almalıdır. Hayvancılık desteklemeleri genellikle yetiştirici birlikleri aracılığıyla yapılmaktadır. Bu nedenle, yetiştiricilerin neden yetiştirici birliklerine üye olmadıklarının sebepleri belirlenmeli ve yetiştirici birliklerine üye olmaları sağlanmalıdır. Giresun ilinde hem yem bitkilerinin yetiştirilmesi için yeterli alanın olmaması ve hem de iklim koşullarının yem bitkilerinin kurutulması için uygun olmamasından dolayı gerek duyulan kaba yem daha uzak yerlerden temin edildiğinden yem maliyetleri artmaktadır. Yem maliyetlerinin azaltılması için gerekli önlemler ilgililer tarafından alınmalıdır. Yem bitkisi ekimine uygun olan arazilerin ekimi için yetiştiriciler teşvik edilmeli ve kaba yemin daha yakın yerlerden satın alınması sağlanmalıdır. Yetiştiriciler işletmelerinde kesif yemi nasıl yapacakları yönünde eğitilmeli ve işletmelerde kesif yem yapımı teşvik edilmelidir. Memede mastitis (meme yangısı) gibi rahatsızlıkların ortaya çıkmaması için yetiştiriciler meme temizliğinin nasıl yapılmas1 gerektiği konusunda bilinçlendirilmelidir. Yetiştiriciler süt analizlerini neden yapmaları gerektiği konusunda bilgilendirilmeli ve süt analizlerinin yaptırılması konusunda yetiştiricilere gerekli destek verilmelidir. Yetiştiriciler işletmelerini projeli ve müstakil olarak yapmaları konusunda bilinçlendirilmeli ve ilgili kurum ya da kuruluşlar tarafından gerekli destekler sağlanmalıdır.

\section{Teşekkür}

Ordu Üniversitesi Bilimsel Araştırma Projeleri Yönetim Birimi'ne sağlamış oldukları maddi destekleri için teşekkür ederiz (Proje No: BY-1707).

\section{Kaynaklar}

Akman N (2006) Türkiye'nin Hayvansal Üretimi. Ziraat Fakültesi Yayınları. Ankara.

Anonim (2008) SPSS İstatistik Paket Programı.

Anonim (2015) Hayvancılık Raporu. Gıda Tarım ve Hayvancılık Bakanlığı, GAP Uluslararası Tarımsal Araştırma ve Eğitim Merkezi Tarımsal Ekonomi ve Politika Araştırmaları Bölüm Başkanlığı, Y1l: 2 Say1: 2.

Anonim (2016) Tarım ve Orman Bakanlığı Hayvan Bilgi Sistemi TürkVet Kayıt Sistemi Giresun İli Verileri.

Anonim (2017) Türkiye İstatistik Kurumu (TÜİK). Hayvansal üretim istatistikleri.

Aydın R, Güler O, Yanar M, Diler A, Koçyiğit R, Avcı M (2016) Erzurum İli Hınıs İlçesi Sığırcılık İşletmelerinin Barınak Özellikleri Üzerine Bir Araştırma. Kahramanmaraş Sütçü İmam Üniversitesi Doğa Bilimleri Dergisi 19(1): 98-42.

Aygül H, Özkütük K (2012) Malatya İli süt Sığırcılı̆̆ı ve Sığır Besiciliğinin Yapısı. Adana Veteriner Kontrol ve Araştırma Enstitüsü Dergisi 2: 7-11.

Bakan Ö, Aydın R (2016) Ağrı İli Süt Sığırcılığı İşletmelerinin SosyoEkonomik Özellikleri. Atatürk Üniversitesi Ziraat Fakültesi Dergisi 47(2): 113-122.

Bakır G (2002) Van ilindeki Özel Süt Sığırcılığı İşletmelerinin Yapısal Durumu. Yüzüncü Y1l Üniversitesi Ziraat Fakültesi Tarım Bilimleri Dergisi 12(2): 1-10.

Bardakçıŏlu HE, Türkyılmaz MK, Nazlıgül A (2004) Aydın İli Süt Sığırcılığı İşletmelerinde Kullanılan Barınakların Özellikleri Üzerine Bir Araştırma. İstanbul Üniversitesi Veteriner Fakültesi Dergisi 30(2): 51-62.

Çağı U, Odabaşıoğlu F (2009) Antakya Yöresi Besi Sığırcılığı İşletmelerinin Bilimsel Değerlendirilmesi. Mustafa Kemal Üniversitesi Ziraat Fakültesi Dergisi 14(2): 69-82.

Demir P (2011) Kars İlindeki süt Üreticilerinin Bazı Teknik Bilgi Düzeylerinin Araştırılması. Atatürk Üniversitesi Veteriner Bilimleri Dergisi 6(1): 47-54.

Demir P, Aral S (2009) Kars İlinde Faaliyet Gösteren Süt Sığırcılık İşletmelerinin Karşılaştıkları Sorunlar ve Çözüm Önerileri. Veteriner Hekimler Derneği Dergisi 80(3): 17-22.

Demir P, Ayvazoğlu C (2012) Hayvancılık İşletmelerinin Veteriner Hekimlik Hizmetlerinden Beklentileri. Kars İli Örneği. Erciyes Üniversitesi Veteriner Fakültesi Dergisi 9(3): 169-174.

Demirtaş M (2006) Manavgat İlçesi Süt Sı̆̆ırcılık İşletmelerinin Genel Profili Üzerine Bir Araştırma. Adnan Menderes Üniversitesi Sağlık Bilimleri Enstitüsü (Yüksek Lisans Tezi).

Hocquette JF, Gigli S (2005) Challange of quality. Indicatorsof Milk and Beef Quality. EAAP Publication No: 112.

Hozman SB, Akçay H (2016) Sivas İli Damızlık Sığır Yetiştiricileri Birliğine Üye Süt Sı̆̆ırcılığı İşletmelerinin Bazı Teknik ve Ekonomik Özellikleri. Tarım Ekonomisi Dergisi 22(1): 57-65.

Karabacak A, Topak R (2007) Ereğli Bölgesinde Süt sığırı Barınaklarının Yapısal Durumu ve Sorunları. Selçuk Üniversitesi Ziraat Fakültesi Dergisi 21(42): 55-58. 
Koçyiğit R, Diler A, Yanar M, Güler O, Aydın R, Avcı M (2015) Erzurum İli Hınıs İlçesi Sığırcılık İşletmelerinin Yapısal Özellikleri: Çiftlik Yönetimi ve Buzağı Yetiştirme Uygulamaları. Iğdır Üniversitesi Fen Bilimleri Enstitüsü Dergisi 5(4): 85-97.

Özyürek S, Koçyiğit R, Tüzemen N (2014) Erzincan İlinde Süt Sığırcılığı Yapan İşletmelerin Yapısal Özellikleri: Çayırlı İlçesi Örneği. Tekirdağ Ziraat Fakültesi Dergisi 11(3): 19-26.

Soyak A, Soysal Mİ, Gürcan EK (2007) Tekirdağ İlindeki Süt Sığırcılığı İşletmelerinin Yapısal Özellikleri ve Bu İşletmelerdeki Siyah Alaca Süt Sığırlarının Çeşitli Morfolojik Özellikleri Üzerine Bir Araştırma. Tekirdağ Ziraat Fakültesi Dergisi 4(3): 297-305.

Şahin K, Gül A, Koç B, Dağıstan E (2001) Adana İlinde Entansif Süt Sığırcılığı Üretim Ekonomisi. Yüzüncü Yıl Üniversitesi Ziraat Fakültesi Tarım Bilimleri Dergisi 11(2): 19-28.

Şahin K, Yılmaz İH (2008) Van İli Gürpınar İlçesinde Yem Bitkileri Üretimi ve Sorunları Üzerine Bir Araştırma. Ankara Üniversitesi, Ziraat Fakültesi Tarım Bilimleri Dergisi 14(1): 16-21.

Şeker İ, Tasalı H, Güler H (2012) Muş İlinde Sığır Yetiştiriciliği Yapılan İşletmelerin Yapısal Özellikleri. Fırat Üniversitesi Sağlık Bilimleri Veteriner Dergisi 26(1): 09-16.
Tapkı İ (1996) Hatay İli Ve Çevresinde Süt Sığırı Yetiştiriciliği Ve Sığır Besiciliği Yapılan Tarım İşletmelerinin, Teknik, Ekonomik Ve Yapısal Özellikleri. Yüksek Lisans Tezi. Mustafa Kemal Üniversitesi Fen Bilimleri Enstitüsü, s. 71, Hatay.

Tapkı N, Tapkı İ, Dağıstan E, Selvi MH, Kaya A, Güzey YZ, Demirtaş B, Çelik AD (2018) Hatay İli Damızlık Sığır Yetiştiricileri Birliği Üyesi İşletmelerin Sosyo-Ekonomik Özellikleri. Journal of Animal Production 59(1): 25-32.

Tugay A, Bakır G (2005) Giresun Yöresindeki Özel Süt Sığırcılığı İşletmelerinin Irk Tercihleri ve Barınakların Yapısal Durumu. Atatürk Üniversitesi Ziraat Fakültesi Dergisi 37(1): 39-47.

Yamane T (1967) Statistics. An Introductory Analysis, 2nd Ed. New York: Harper and Row.

Yener H, Atalar B, Mundan D (2013) Şanlıurfa İlindeki Sı̆̆ırcılık İşletmelerinin Biyogüvenlik ve Hayvan Refahı Açısından Değerlendirilmesi. Harran Üniversitesi Veteriner Fakültesi Dergisi 2(2): 87-93. 